Tanjungpura Law Journal, Vol. 4, Issue 2, July 2020: 95 - 116

ISSN Print: 2541-0482 | ISSN Online: 2541-0490

Open Access at: http://jurnal.untan.ac.id/index.php/tlj

Article Info

Submitted: 25 Februari 2020 | Reviewed: 15 April 2020 | Accepted: 28 Mei 2020

\title{
POLITIK HUKUM PERLINDUNGAN PEKERJA MIGRAN INDONESIA DALAM PERSPEKTIF FIKIH SIYASAH DUSTURIYAH
}

\author{
Dani Amran Hakim, ${ }^{1}$ Muhammad Havez ${ }^{2}$
}

\begin{abstract}
This article discusses the politics of law for Indonesian migrant workers protection. The aim of discussion is to understand the politics of law for Indonesian migrant workers protection in siyasah dusturiyah figh perspective based on Law Number 18 Year 2017 about Indonesian Migrant Workers Protection. The method used is literature review using a juridicial normative approach and content analyisis. The Article 3 of the Law on the Protection of Indonesian Migrant Workers states that Indonesian migrant workers protection aim to protect the human rights as well as to fulfil the legal, economic and social needs of migrant workers and their families. The protection is conducted before, during and after their working time. Based on the perspective of siyasah dusturiyah figh which is a part of siyasah figh that addresses the issue of legislation of state, so the Law on the Protection of Indonesian Migrant Workers is in accordance with 4 (fourth) principles of workers protection in Islam, they are 1) human independency; 2) human dignity; 3) justice; 4) contract (akad) and payment clarity.
\end{abstract}

Keywords: Indonesian migrant workers; protection; siyasah dusturiyah

\begin{abstract}
Abstrak
Tulisan dalam artikel ini membahas mengenai politik hukum perlindungan pekerja migran Indonesia. Tujuannya untuk mengetahui perspektif fikih siyasah dusturiyah terhadap perlindungan pekerja migran Indonesia berdasarkan Undang-Undang Nomor 18 Tahun 2017 tentang Perlindungan Pekerja Migran Indonesia.Metode yang digunakan adalah kajian pustaka dengan menggunakan pendekatan yuridis normatif dan analisis konten. Berdasarkan Pasal 3 Undang-Undang Perlindungan Pekerja Migran Indonesia memberikan arah tujuan yang hendak dicapai dalam perlindungan pekerja migran Indonesia yaitu menjamin pemenuhan dan penegakan hak asasi manusia para pekerja migran serta menjamin perlindungan hukum, ekonomi dan sosial pekerja migran serta keluarganya. Perlindungan tersebut dilaksanakan sebelum, selama dan setelah bekerja. Berdasarkan fikih siyasah dusturiyah, yang merupakan bagian fikih siyasah yang membahas masalah perundang-undangan negara, maka Undang-Undang Perlindungan Pekerja Migran Indonesia ditinjau dari perspektif tersebut sesuai dengan 4 (empat) prinsip ketenagakerjaan dalam Islam yaitu; 1) kemerdekaan manusia; 2) prinsip kemuliaan derajat manusia; 3) prinsip keadilan; dan 4) prinsip kejelasan akad (perjanjian) dan transaksi upah.
\end{abstract}

Kata Kunci: perlindungan; pekerja migran Indonesia; siyasah dusturiyah

\footnotetext{
${ }^{1}$ Fakultas Syari'ah, Universitas Islam Negeri Raden Intan Lampung, Jln. Letnan Kolonel Endro Suratmin, Sukarame, Bandar Lampung, 35131, Email: daniamranhakim@radenintan.ac.id, Tlp. 082181111307

2 Firma Hukum HAR \& Partners, Jln. Rya Cudu Pembangunan A6 No. 1, Sukarame, Bandar Lampung, 35131, Email: havez02@gmail.com, Tlp.085339390202
} 


\section{Pendahuluan}

Berdasarkan Pasal 27 ayat (2) Undang-Undang Dasar Negara Kesatuan Republik Indonesia (UUD NKRI) 1945 menentukan bahwa,“ Tiap-tiap warga Negara berhak atas pekerjaan dan penghidupan yang layak bagi kemanusiaan", dengan demikian jaminan atas penyediaan lapangan pekerjaan merupakan pemenuhan hak dasar yang melekat dan dilindungi oleh konstitusi dan negara Indonesia. Kedaulatan sebuah negara dituangkan dalam konstitusi yang mengatur dasar-dasar bernegara dan jaminan atas hak dan kewajiban warga negaranya. Namun pada kenyataannya, keterbatasan akan lapangan pekerjaan di dalam negeri menyebabkan banyaknya warga negara Indonesia mencari pekerjaan ke luar negeri menjadi pekerja migran. Menurut Connie de la Vega pengertian pekerja migran adalah "a person who is to be engaged, is engaged or has been engaged in a remunerated activity in a State of which he or she is not a national." $3 \mathrm{Hal}$ tersebut semakin meningkat sejak krisis ekonomi melanda negara Indonesia pada akhir tahun 1997, jumlah Tenaga Kerja Indonesia atau Pekerja Migran Indonesia (selanjutnya

\footnotetext{
${ }^{3}$ Connie De La Vega dan Conchita Lozano-Batista. 2016." 21 Advocates Should Use Applicable International Standards to Address Violations of Undocumented Migrant Workers 'Rights in the United States," dalam Human Rights and Refugees, Internally Displaced Persons and Migrant Workers, ed. oleh Anne F. Bayefsky (Martinus Nijhoff Publishers, 2006), hlm. 517.
}

disingkat $\mathrm{PMI}$ ) ke luar negeri meningkat tajam. ${ }^{4}$

Peningkatan tersebut disebabkan semakin sempitnya lapangan pekerjaan yang tersedia di dalam negeri, sehingga memaksa banyak warga negara Indonesia menjadi pekerja migran di luar negeri untuk mempertahankan hidup. Berdasarkan data yang bersumber dari Badan Pusat Satistik (BPS) mencatat Agustus 2019 ada sejumlah 8,13 juta orang setengah penganguran (orang yang bekerja kurang dari 35 jam seminggu dan masih bersedia menerima pekerjaan) dan 28,41 juta orang pekerja waktu (orang yang bekerja di bawah jam kerja normal dari 35 jam seminggu tetapi tidak mencari pekerjaan atau tidak bersedia menerima pekerjaan lain, terdapat 5 orang penganggur dari 100 orang angkatan kerja. ${ }^{5}$ Dengan tingkat pengangguran yang cukup tinggi ini, artinya negara belum dapat menyediakan lapangan pekerjaan yang memadai. Hal ini menjadi persoalan di negara-negara berkembang seperti Indonesia.

Selanjutnya pemerintah mencatat ada kenaikan jumlah angkatan kerja pada Februari 2020 sebanyak 137,91 juta orang, naik 1,73 juta orang dibanding

\footnotetext{
${ }^{4}$ Rizky Dian Bareta dan Budi Ispriyarso. 2018. "Politik Hukum Perlindungan Tenaga Kerja Indonesia Fase Purna Bekerja," Kanun Jurnal IImu Hukum 20 (1), hlm. 163.

5 Badan Pusat Statistik Indonesia. 2019. Berita Resmi Statistik Keadaan Ketenagakerjaan Indonesia 2019, hlm. 1.
} 
Februari 2019. ${ }^{6}$ Masalah minimnya lapangan pekerjaan dan mewabahnya virus Covid-19 di Indonesia sejak bulan Maret 2020 yang memaksa pemerintah membuat kebijakan Pembatasan Sosial Berskala Besar (PSBB) tentunya berdampak pada perekonomian khususnya swasta atau perusahaan yang tidak sedikit melakukan pemutusan hubungan kerja kepada pegawainya. Permasalahan tersebut masih ditambah dengan masalah kemiskinan yang mendera masyarakat Indonesia. Hal tersebut menjadi faktor pendorong yang cukup besar dengan keberadaan PMI di luar negeri. Kesempatan lapangan pekerjaan dan tingkat penghasilan yang cukup tinggi di luar negeri menjadi daya tarik utama dari para PMI. ${ }^{7}$

Berdasarkan Pasal 31 UndangUndang Nomor 13 Tahun 2003 tentang Ketenagakerjaan (UUTK) menentukan bahwa "Setiap tenaga kerja mempunyai hak dan kesempatan yang sama untuk memilih, mendapatkan atau pindah pekerjaan dan memperoleh penghasilan yang layak di dalam atau di luar negeri". Maka dari itu faktor keterbatasan lapangan pekerjaan, daya saing yang tinggi dan penghasilan yang lebih layak

\footnotetext{
6 Badan Pusat Statistik Indonesia. 2020. Berita Resmi Statistik Keadaan Ketenagakerjaan Februari 2020, hIm. 1.

${ }^{7}$ Hamdan Tri Atmaja, 2014. "Model Pemberdayaan Keluarga Tenaga Kerja Wanita (TKW) Indonesia Berbasis Arena Produksi Kultural Dalam Upaya Menciptakan Keluarga Mandiri Sejahtera di Propinsi Jawa Timur," Forum IImu Sosial, Fakultas IImu Sosial Universitas Negeri Semarang 41 (1), hlm. 26.
}

merupakan alasan yang membuat tenaga kerja yang mencari lowongan pekerjaan di dalam negeri merubah pencariannya ke luar negeri sehingga tidak sedikit masyarakat Indonesia yang menjadi PMI di luar negeri. Sebagian besar pekerja migran ini umumnya terdorong oleh upah yang relatif lebih tinggi dibanding upah yang diterima di negara asal. ${ }^{8}$

Sepanjang 2014-Maret 2019, jumlah PMI mencapai 1,55 juta pekerja. Data dari Badan Nasional Penempatan dan Perlindungan Tenaga Kerja Indonesia (BNP2TKI) sepanjang bulan Januari-Agustus 2017 telah berhasil menempatkan sebanyak 148.285 orang, sepanjang 2018 meningkat 7,89\% menjadi 283.640 orang dan populasi selama triwulan pertama 2019 mencapai 64.062 orang. ${ }^{9}$ Besarnya jumlah PMI yang bekerja di luar negeri sebenarnya mempunyai sisi positif, yaitu mengatasi sebagian masalah pengangguran di dalam negeri. Namun, ada pula sisi negatifnya berupa resiko kemungkinan terjadinya perlakuan yang tidak manusiawi seperti pelanggaran HAM terhadap pekerja migran. Resiko tersebut dapat dialami oleh PMI baik selama proses persiapan, keberangkatan dan

\footnotetext{
8 Tri Lisiani Prihatinah, Noor Asyik, dan Kartono Kartono, 2012. "Kendala Perlindungan Hukum Terhadap Buruh Migran di Kabupaten Cilacap," Jurnal Dinamika Hukum 12 (2), hlm. 313.

${ }^{9}$ Aga Natalis dan Budi Ispriyarso. 2018. "Politik Hukum Perlindungan Pekerja Migran Perempuan di Indonesia," Pandecta: Research Law Journal 13 (2), hlm. 109.
} 
selama bekerja di luar negeri maupun setelah pulang ke Indonesia.

Bekerja merupakan salah satu kegiatan penting bagi kehidupan manusia bahkan terkadang menjadi sangat dominan dibandingkan dengan aktifitasaktifitas lainnya terutama dalam pemenuhan kebutuhan hidup. Kerja dapat diartikan secara umum maupun khusus, secara umum kerja mencakup semua bentuk usaha yang dilakukan oleh manusia, baik dalam mencari materi maupun non-materil, intelektual atau fisik, maupun hal-hal yang berkaitan dengan masalah dunia maupun akhirat. ${ }^{10}$ Agama Islam menempatkan setiap manusia, apa pun jenis pekerjaan dan profesinya dalam posisi yang mulia dan terhormat. Islam juga sangat mencintai umat Muslim yang gigih bekerja untuk kehidupannya.

Azyumardi Azra memberikan pendapat bahwa Indonesia mengalami transisi dari otoritarianisme sejak tahun 1998. Selang masa dua dasawarsa atau 20 tahun demokrasi, Islam yang merupakan agama mayoritas penduduk juga terus mengalami 'kebangkitan' (resurgence). Berbarengan dengan Islamic resurgence yang bermula sejak separuh kedua dasawarsa 1980an, politik dan demokrasi juga sudah sampai pada titik yang tidak mungkin dimundurkan lagi (point of no return). ${ }^{11}$ Kebangkitan

\footnotetext{
10 M.B. Hendri Anto. 2003, Pengantar Ekonomi Mikro Islam, Yogyakarta: Ekonisia UII, hlm. 222.

${ }^{11}$ Azyumardi Azra, 2018. "Kesalehan dan Politik: Islam Indonesia," Studia Islamika, hlm. 645.
}

tersebut juga tentu mempengaruhi pemerintah untuk membuat peraturan atau kebijakan yang tentunya sesuai atau selaras dengan hal tersebut.

Berdasarkan Pasal 28A UUD 1945 menentukan bahwa" Setiap orang berhak untuk hidup serta berhak mempertahankan hidup dan kehidupannya" dengan demikian bahwa Negara Republik Indonesia berkewajiban melindungi hak hidup serta mempertahankan hidup dan kehidupan segenap warga negara Indonesia. Tanpa ada pengecualian, negara akan melindungi warga negara yang berada baik di dalam maupun luar wilayah Negara Kesatuan Republik Indonesia. Berdasarkan hal tersebut maka pemerintah mengeluarkan kebijakan berupa peraturan perundang-undangan yang bertujuan untuk melindungi pekerja migran Indonesia (PMI), yaitu UndangUndang Nomor 18 Tahun 2017 tentang Perlindungan Pekerja Migran Indonesia (selanjutnya disingkat UU PPMI).

Berdasarkan Pasal 1 angka 2 UU PPMI memberikan pengertian Pekerja Migran Indonesia adalah setiap warga negara Indonesia yang akan, sedang atau telah melakukan pekerjaan dengan menerima upah di luar wilayah Republik Indonesia. Pekerja migran ada disemua sektor ekonomi. Pekerja migran memainkan peran penting dalam pertumbuhan ekonomi baik bagi negara asal (home state) maupun negara tempat mereka bekerja (host state). Sehingga 
negara wajib menjamin perlindungan PMI di negara tempatnya bekerja. Maka dari itu politik hukum perlindungan PMI berdasarkan UU PPMI dikaji apakah telah sesuai dengan tuntutan masyarakat pekerja kita yang membutuhkan perlindungan di luar negeri dan telah selaraskah jika dianalisis berdasarkan figh siyasah dusturiyah. Oleh karena itu menarik untuk mengkaji bagaimana pengaruh agama Islam dalam hal ini perspektif fikih siyasah dusturiyah terhadap Undang-Undang Nomor 18 tahun 2017 tentang Perlindungan Pekerja Migran Indonesia (UU PPMI).

\section{Metode}

Metode penelitian yang digunakan dalam tulisan ini adalah metode penelitian yuridis normatif dengan fokus pada pendekatan perundang-undangan (statute approach) dan analisis konten. Menurut Soerjono Soekanto penelitian yuridis normatif adalah penelitian hukum kepustakaan. 12 Spesifikasi penelitian dalam penulisan ini adalah deskriptifanalitis, artinya bahwa penelitian ini termasuk lingkup penelitian yang menggambarkan, menelaah dan menjelaskan secara tepat serta menganalisa politik hukum peraturan perundang-undangan yang berkaitan dengan perlindungan hukum PMI serta dianalisis berdasarkan figh siyasah dusturiyah.

\footnotetext{
12 Soerjono Soekanto. 2006. Penelitian Hukum Normatif, Rajawali Pub, hlm. 14.
}

\section{Analisis dan Pembahasan}

\section{a. Politik Hukum Perlindungan}

\section{Perkerja Migran Indonesia}

Menurut Hans Kelsen produk hukum mempunyai kekuatan berlaku apabila penetapannya didasarkan atas kaedah yang lebih tinggi tingkatannya. Norma dasar yaitu konstitusi atau grundnorm terdapat dasar berlakunya semua kaedah yang berasal dari satu tata hukum. Berdasarkan grundnorm itu hanya dapat dijabarkan berlakunya suatu kaedah hukum. ${ }^{13}$ Pada tataran grundnorm perlindungan PMI secara konstitusional politik hukum Indonesia mengacu pada Undang-Undang Dasar Negara Republik Indonesia 1945 yang telah terakomodir pada perubahan UUD Negara Republik Indonesia 1945 yang kedua, yaitu penjabaran hak asasi manusia ke dalam konstitusi Republik Indonesia. 14 Berdasarkan Pasal 27 ayat (2) UUD 1945 menentukan bahwa "Tiap-tiap warga negara berhak atas pekerjaan dan penghidupan yang layak bagi kemanusiaan", kemudian Pasal 28A UUD 1945 menentukan bahwa" Setiap orang berhak untuk hidup serta berhak mempertahankan hidup dan kehidupannya.". Selanjutnya Pasal 28D ayat (1) UUD 1945 menentukan bahwa "Setiap orang berhak atas pengakuan,

\footnotetext{
13 Hans Kelsen. 2008. Rechtswetenschap en Gerechtigheid, terjemahan Mr. Ir. MM ban Praag, dikutip oleh Sudikno Mertokusumo, Mengenal Hukum Suatu Pengantar, Yogyakarta: Liberty, hlm. 95.

${ }^{14}$ Bareta dan Ispriyarso, Op. Cit., hlm. 170.
} 
jaminan, perlindungan, dan kepastian hukum yang adil serta perlakuan yang sama di hadapan hukum." Selanjutnya Pasal 28D ayat (2) UUD 1945 menentukan bahwa" Setiap orang berhak untuk bekerja serta mendapat imbalan dan perlakuan yang adil dan layak dalam hubungan kerja."15

Maka perlindungan PMI merupakan kewajiban yang telah disepakati dalam grundnorm atau kosntitusi yang berlaku di negara kita yaitu UUD 1945. Perlindungan PMI tersebut dijabarkan melalui UU PPMI, berdasarkan Pasal 1 angka 5 UU PPMI menentukan bahwa, Perlindungan Pekerja Migran Indonesia adalah segala upaya untuk melindungi kepentingan Calon Pekerja Migran Indonesia dan/atau Pekerja Migran Indonesia dan keluarganya dalam mewujudkan terjaminnya pemenuhan haknya dalam keseluruhan kegiatan sebelum bekerja, selama bekerja, dan setelah bekerja dalam aspek hukum, ekonomi, dan sosial.

$$
\text { Kebijakan }
$$

pengaturan

perlindungan pekerja migran melalui UU PPMI merupakan bagian dari politik hukum negara Indonesia. Menurut David Kairsy, politik hukum merupakan kebijaksanaan negara untuk menerapkan hukum. ${ }^{16} \mathrm{E}$. Utrecht memaparkan bahwa politik hukum adalah suatu ilmu normatif

\footnotetext{
15 Ibid

${ }^{16}$ David Kairys, ed., 1990. The Politics of Law: A Progressive Critique, Revised ed. (2nd ed.), New York: Pantheon Books, hlm. xi.
}

yaitu ilmu yang menentukan hal-hal yang seharusnya ada. ${ }^{17}$ Sesuatu yang seharusnya ada dalam bentuk normatif adalah peraturan perundang-undangan, baik yang bersifat materiil maupun formil. Politik hukum kemudian berperan untuk menentukan cara dan tujuan yang hendak dicapai dalam pembuatan ataupun pelaksanaan suatu produk hukum. ${ }^{18}$ Menurut Parsons dalam politik hukum, ada beberapa hal yang menjadi persoalan, yaitu: 1) tujuan yang hendak dicapai dengan sistem hukum yang ada; 2) cara-cara terbaik untuk mencapai tujuan; 3) kapan waktu hukum perlu diubah dan bagaimana caranya; 4) perumusan suatu pola untuk proses pemilihan tujuan serta cara pencapaiannya. 19 Berdasarkan pengertian tersebut menurut Mahfud MD melihat politik hukum mencakup proses pembuatan dan pelaksanaan hukum yang dapat menunjukkan sifat dan ke arah mana hukum dibangun dan ditegakkan. ${ }^{20}$

1. Perkembangan

Hukum

Perlindungan Pekerja Migran Indonesia

Sebelum berlakunya UU PPMI, pada tanggal 18 Oktober 2004, Pemerintah Indonesia mengesahkan

17 Otong Rosadi dan Andi Desmon. 2013, Studi Politik Hukum: Suatu Optik Politik Hukum, Yogyakarta: PT. Thafa Media, hlm. 6.

18 Satjipto Rahardjo. 2009, Hukum dan Perubahan Sosial (Yogyakarta: Genta Publishing, hlm. 203.

19 Talcott Parsons. 1966, Societiers, Evolutionary and Comparative Perspectives, Englewood Cliff, New Jersey: Prentice Hall, hlm. 13.

20 Moh. Mahfud M. D, 2009, Politik Hukum di Indonesia, Jakarta: Rajawali Pers, hlm. 9. 
sebuah undang-undang yang mencoba untuk melindungi hak asasi para pekerja migran melalui Undang-Undang Nomor 39 Tahun 2004 tentang Penempatan dan Perlindungan Tenaga Kerja Indonesia di Luar Negeri (UU PPTKILN). Namun setelah diberlakukan ternyata penolakan terhadap keberadaan UU PPTKILN marak terjadi dan tak kunjung padam. Pengaturan perlindungan PMI ini tentunya bertujuan agar pemerintah dapat memberikan kebijakan yang baik kepada para PMI, menurut Widaningrum penerimaan publik atau masyarakat terhadap pengaturan atau kebijakan yang dikeluarkan pemerintah membutuhkan kepercayaan publik yang tinggi, "high public trust in government will facilitate government in implementing various policies, because the public believes that the government has a concern for the public interest and demands. 21 Sedangkan pengaturan PMI pada UU PPTKILN sangat marak terjadi penolakan oleh berbagai lapisan di masyarakat.

Penolakan dan perlawanan paling keras datang dari kalangan Lembaga Swadaya Masyarakat (LSM) yang menganggap bahwa kebijakan pemerintah dalam UU PPTKILN memandang buruh migran alias PMI tak lebih sebagai komoditas. ${ }^{22}$ Implementasi

\footnotetext{
21 Ambar Widaningrum. 2017, "Public Trust and Regulatory Compliance," Jurnal IImu Sosial dan IImu Politik 21 (1), hlm. 11.

22 Pemerintah Hanya Jadikan TKI Sebagai Komoditas,
}

kebijakan pemerintah masih mengandung semangat diskriminasi dan bahkan kebijakan penempatan buruh migran sudah mengarah pada kebijakan perdagangan manusia (human trafficking). ${ }^{23}$

Maraknya penolakan dan tanggapan negatif terhadap UU PPTKILN maka pada 12 April 2012 Dewan Perwakilan Rakyat mengesahkan undang-undang mengenai ratifikasi International Convention on The Protection of The Rights of All Migrant Workers and Members of Their Families melalui Undang-Undang Nomor 6 Tahun 2012 tentang Pengesahan International Convention on The Protection of The Rights of All Migrant Workers and Members of Their Families (Konvensi Internasional Mengenai Perlindungan Hak-Hak Seluruh Pekerja Migran dan Anggota Keluarganya atau dapat disingkat menjadi Konvensi Migran 1990). Berdasarkan undang-undang ini kemudian substansi perlindungan terhadap pekerja migran dan keluarganya

http://www.eramoslem.com/br/fo/48/12377,1v.ht $\mathrm{ml}$, t.t. diakses pada tanggal 25 Desember 2019

23 "Komnas HAM, "Hak Asasi Buruh Migran Indonesia," http://www. Tempointeraktif.com/hg/narasi/2004/06/17/nrs,20 040617-07,id.html, t.t.; diunduh pada tanggal 25 Desember 2019" Depnakertrans Bantah RUU Perlindungan TKI Mengukuhkan Trafficking," http://www.tempointeraktif.com/hg/nasional/2004/ 09/17/brk,20040917-31,id.html, t.t.; diunduh pada tanggal 25 Desember 2019 atau lihat juga dalam "Laporan Akhir Analisis Dan Evaluasi Hukum Mengenai Perlindungan Hak Dan Keselamatan Pekerja Migran" (Pusat Analisis Dan Evaluasi Hukum Nasional Badan Pembinaan Hukum Nasional Kementerian Hukum Dan Hak Asasi Manusia, 2016). 
diatur lebih mendalam dibanding UndangUndang Nomor 39 Tahun 2004. ${ }^{24}$

Sampai pada akhirnya bulan Oktober tahun 2017 Pemerintah dan Dewan Perwakilan Rakyat secara resmi mengesahkan RUU Perlindungan Pekerja Migran Indonesia menjadi UndangUndang Nomor 18 Tahun 2017 tentang Perlindungan Pekerja Migran Indonesia (UU PPMI) untuk menggantikan UndangUndang Nomor 39 Tahun 2004 tentang Penempatan dan Perlindungan Tenaga Kerja Indonesia Di Luar Negeri. Pengesahan ini menandakan akhir dari perjalanan panjang yang lamban dan terjal dari proses legislasi untuk perlindungan pekerja migran Indonesia yang setiap saat menghadapi kerentanan pelanggaran HAM, mulai dari soal pengupahan, pengusiran, penganiayaan, pelecehan seksual, perkosaan bahkan hukuman mati.

Berdasarkan UU PPMI merujuk pada pengertian tentang konsepsi politik hukum di atas, Pasal 3 UU PPMI memberikan arah tujuan yang hendak dicapai dalam perlindungan PMI yaitu; a) menjamin pemenuhan dan penegakan hak asasi manusia sebagai warga negara dan Pekerja Migran Indonesia; dan b) menjamin perlindungan hukum, ekonomi dan sosial Pekerja Migran Indonesia dan keluarganya. Perlindungan hak asasi manusia menurut UU PPMI adalah pekerja migran Indonesia harus dilindungi

${ }^{24}$ Bareta dan Ispriyarso, Op. Cit., 172. dari perdagangan manusia, perbudakan dan kerja paksa, korban kekerasan, kesewenang-wenangan, kejahatan atas harkat dan martabat manusia, serta perlakuan lain yang melanggar hak asasi manusia.

Pokok-pokok pengaturan dalam UU PPMI meliputi pekerja migran Indonesia yang bekerja pada pemberi kerja berbadan hukum, pekerja migran Indonesia yang bekerja pada pemberi kerja perseorangan, pelaut awak kapal dan pelaut perikanan, hak dan kewajiban pekerja migran Indonesia dan keluarganya, upaya perlindungan PMI baik perlindungan dalam sistem penempatan (sebelum bekerja, selama bekerja, dan sesudah bekerja), atase ketenagakerjaan, layanan terpadu satu atap, sistem pembiayaan yang berpihak pada calon dan/atau PMI, penyelenggaraan Jaminan Sosial Pekerja Migran Indonesia, dan perlindungan hukum, sosial, dan ekonomi.

Secara kewenangan pemerintah dalam pelaksanaannya UU PPMI mengatur tugas dan tanggung jawab antara pemerintah pusat dan pemerintah daerah. Tugas dan tanggung jawab tersebut diatur dalam Bab V Pasal 39-43 UU PPMI. Selain itu berdasarkan Pasal 1 angka 5 UU PPMI menentukan bahwa, perlindungan pekerja migran Indonesia adalah segala upaya untuk melindungi kepentingan calon dan/atau PMI serta keluarganya dalam mewujudkan terjaminnya pemenuhan haknya dalam 
keseluruhan kegiatan sebelum bekerja, selama bekerja, dan setelah bekerja dalam aspek hukum, ekonomi dan sosial.

\section{Perlindungan Sebelum, Selama dan Setelah Bekerja}

Perlindungan dalam UU PPMI diatur secara lebih sistematis dan komprehensif dalam bab tersendiri yaitu terdiri dari aturan Perlindungan sebelum, selama dan setelah bekerja berjumlah sebanyak 20 pasal, serta aturan terkait perlindungan hukum, ekonomi, dan sosial yang berjumlah sebanyak 6 pasal. Pengaturan perlindungan terhadap PMI sebelum bekerja berdasarkan Pasal 8 mencakup 2 aspek yaitu administratif dan teknis.

\section{Perlindungan yang bersifat} administratif meliputi kelengkapan dan keabsahan dokumen penempatan serta penetapan kondisi dan syarat kerja seperti surat keterangan perkawinan, surat keterangan izin pihak keluarga, surat keterangan sehat, sertifikat kompetensi kerja, paspor, visa kerja, perjanjian penempatan, dan perjanjian kerja. Sementara terkait proses yang dipersyaratkan berdasarkan Pasal 12 ayat 2 akan diatur lebih lanjut dalam Peraturan Kepala Badan. Perlindungan pada aspek teknis meliputi antara lain sosialisasi informasi, pendidikan dan pelatihan, fasilitas pemenuhan hak, pelayanan dalam bentuk layanan terpadu satu atap (LTSA), jaminan sosial, penguatan pegawai fungsional, dan pembinaan serta pengawasan.
Bagian ini juga memuat tugas dan tanggung jawab atase ketenagakerjaan yaitu pada Pasal 15 yang mengatur verifikasi terhadap mitra usaha (agen perekrutan) di luar negeri dan pengguna jasa. Atase ketenagakerjaan juga berkewajiban untuk membuat serta mengumumkan daftar mitra usaha dan pengguna jasa yang bermasalah secara periodik berdasarkan verifikasi tersebut. Hasil verifikasi akan digunakan sebagai bahan rekomendasi dalam pemberian izin penempatan bagi Perusahaan Penempatan Pekerja Migran Indonesia (PPPMI) yang bermitra dengan mitra usaha yang masuk dalam daftar bermasalah (blacklisting). Selanjutnya pada Pasal 19 ayat 2 mengatur bagian perlindungan sebelum bekerja mengatur tentang isi perjanjian kerja, jangka waktu perjanjian kerja, prosedur perpanjangan perjanjian kerja, serta sanksi administratif bagi PPPMl yang tidak menempatkan calon PMI sesuai yang tercantum dalam perjanjian kerja.

Selanjutnya pada bagian aturan mengenai perlindungan setelah bekerja, berdasarkan Pasal 24 UU PPMI membaginya ke dalam 5 cakupan isu yaitu fasilitas kepulangan hingga daerah asal, penyelesaian hak, fasilitas pengurusan PMI sakit/meninggal dunia, rehabilitasi dan reintegrasi sosial, serta pemberdayaan bagi PMI dan keluarganya. Selebihnya, bagian ini lebih banyak mengatur mengenai kewajiban PPMI untuk melaporkan data kedatangan 
dan kepulangan PMI yaitu pada Pasal 25 serta kewajiban dalam hal pengurusan PMI yang meninggal dunia pada Pasal $27 .{ }^{25}$

\section{Penguatan Peran Pemerintah}

Berdasarkan aturan terdahulu yaitu, Undang-Undang Nomor 39 Tahun 2004 tentang Penempatan dan Perlindungan Tenaga Kerja Indonesia di Luar Negeri (UU PPTKILN), peran swasta dinilai sangat dominan di semua tahap migrasi mulai dari memberikan informasi, pendataan, pengurusan dokumen, menyelenggarakan pendidikan, prapemberangkatan, penampungan, medical check up, proses pemberangkatan, penyelesaian masalah hingga mengurus kepulangan. Hal ini menjadi salah satu faktor utama yang menyebabkan PMI dan keluarganya memiliki situasi rentan terhadap berbagai pelanggaran HAM serta menjerat mereka ke dalam persoalan-persoalan yang rumit.

Melalui UU PPMI negara memiliki legitimasi yang kuat untuk memberikan jaminan, perlindungan, dan pemenuhan hak PMI dan keluarganya dengan mengurangi peran swasta dalam penempatan dan perlindungan PMI. Dalam UU ini, tata kelola migrasi tenaga kerja yang sebelumnya sentralistik menjadi desentralisasi dengan pelibatan pemerintah daerah mulai dari Provinsi

25 Savitri Wisnuwardhani. 2018, Memahami Undang-Undang Perlindungan Pekerja Migran Indonesia: Kelebihan dan Kelemahan UU PPMI, Jakarta: Jaringan Buruh Migran: The Institute for Ecosoc Rights, hlm. 2-3. hingga Desa. Penguatan peran pemerintah baik di tingkat pusat dan daerah menunjukkan komitmen negara untuk memberikan perlindungan kepada PMI dan penghormatan hak asasi manusia. Berdasarkan Pasal 52 menentukan bahwa tugas dan tanggung jawab PPPMI dalam UU PPMI adalah mencari peluang kerja, menempatkan, dan menyelesaikan masalah.

Undang-Undang ini mengatur tugas dan wewenang Pemerintah Pusat dan Pemerintah Daerah, serta peran dan fungsi badan sebagai pelaksana kebijakan perlindungan PMI. Berdasarkan Undang-Undang ini, Badan Nasional Penempatan dan Perlindungan Tenaga Kerja Indonesia (BNP2TKI) yang dibentuk atas Undang-Undang Nomor 39 Tahun 2004 sejak tahun 2019 berubah nama menjadi Badan Perlindungan Pekerja Migran Indonesia (BP2MI) dan diperkuat fungsi dan perannya sebagai pelaksana perlindungan bagi Pekerja Migran Indonesia. Pelaksanaan perlindungan PMI membutuhkan pengawasan dan penegakan hukum yang tegas. Pengawasan mencakup perlindungan sebelum bekerja, selama bekerja, dan setelah bekerja. Penegakan hukum meliputi sanksi administratif dan sanksi pidana.

Berdasarkan uraian diatas, secara keseluruhan substansi UU PPMI telah mengadopsi semangat perlindungan dalam Konvensi Migran 1990 International Convention on The 
Protection of The Rights of All Migrant Workers and Members of Their Families, meskipun belum pada seluruh aspek migrasi. ${ }^{26}$ Selain itu, UU PPMI juga mengatur mengenai asas-asas yang menjadi dasar perlindungan PMI. Berdasarkan Pasal 2 UU PPMI perlindungan pekerja migran Indonesia memiliki asas: a) keterpaduan; b) persamaan hak; c) pengakuan atas martabat dan hak asasi manusia; d) demokrasi; e) keadilan sosial; f) kesetaraan dan keadilan gender; g) nondiskriminasi; h) anti-perdagangan manusia; i) transparansi; j) akuntabilitas; dan k) berkelanjutan.

\section{B. Perskpektif Fiqh Siyasah}

Dusturiyah Terhadap Perlindungan Pekerja Migran Indonesia

Kata fikih berasal dari faqahayafqahu-fiqhan. Secara bahasa, pengertian fikih adalah paham yang mendalam. ${ }^{27}$ Secara etimologis, fikih adalah keterangan tentang pengertian atau pemahaman yang mendalam terhadap maksud-maksud perkataan dan perbuatan. ${ }^{28}$ Dari definisi ini dapat dipahami bahwa fikih adalah upaya sungguh-sungguh dari para ulama (mujtahidin) untuk menggali hukumhukum syara' sehingga dapat diamalkan

\footnotetext{
${ }^{26}$ Ibid, hlm. 4.

27 Muhammad lqbal. 2001, Fiqh Siyasah: Kontekstualisasi Doktrin Politik Islam, Jakarta: Gaya Media Pratama, hIm. 2.

28 J. Suyuthi Pulungan. 1999, Fiqh Siyasah: Ajaran, Sejarah dan Pemikiran, Jakarta: PT RajaGrafindo Persada, hlm. 21.
}

oleh umat Islam. Kata siyasah berasal dari kata 'sasa yang mengandung beberapa arti yaitu, mengatur, mengurus, memerintah, memimpin, membuat kebijaksanaan, pemerintahan dan politik. ${ }^{29}$ Berdasarkan pengertian tersebut maka dapat ditarik kesimpulan bahwa fikih siyasah merupakan salah satu aspek hukum Islam dalam bernegara demi mencapai kemaslahatan bagi manusia itu sendiri. Fikih siyasah mengkaji dengan spesialisasi segala ihwal dan seluk-beluk tata pengaturan negara dan pemerintahan. ${ }^{30}$

Menurut Imam al-Mawardi, di dalam kitabnya yang berjudul al-Ahkam al-Shultaniyyah, lingkup kajian fikih siyasah mencakup kebijaksanaan tentang siyasah dusturiyah (peraturan perundangundangan), siyasah maliyyah (ekonomi dan moneter), siyasah qadha'iyyah (peradilan), siyasah harbiyah (hukum perang), siyasah iddariyyah (administrasi negara) dan siyasah dauliyah (hubungan internasional). ${ }^{31}$ Menurut Muhammad lqbal pembagian fikih siyasah tersebut dapat disederhanakan menjadi tiga bagian pokok. Pertama, politik perundang-undangan (siyasah dusturiyah). Kedua, politik luar negeri (siyasah dauliyyah). Ketiga, politik

\footnotetext{
${ }^{29}$ Ibn Manzhur. 1968, Lisan al-Arab, Juz 6, Beirut: Dar al-Shadr, hlm. 108.

$30 \mathrm{~J}$. Suyuthi Pulungan, Op. Cit., hlm. 27.

31 Ibn Taimiyah, Siyasah al-Syar'iyah fi Ishlah alRa'l wa al-Ra'iyah, Mesir: Dar al-Kitab al-Arabi, hIm. 15.
} 
keuangan dan moneter (siyasah maliyyah). ${ }^{32}$

Kata dusturiyah berasal dari bahasa Persia yang berarti dusturi. ${ }^{33}$ Semula artinya adalah seorang yang memiliki otoritas, baik dalam bidang politik maupun agama. ${ }^{34}$ Setelah mengalami penyerapan ke dalam bahasa Arab, kata dusturiyah berkembang pengertiannya menjadi asas dasar atau pembinaan. Siyasah dusturiyah adalah bagian fikih siyasah yang membahas masalah perundang-undangan negara.

Pembahasannya antara lain melingkupi konsep-konsep konstitusi (undangundang dasar negara dan sejarah lahirnya perundang-undangan dalam suatu negara), legislasi (bagaimana cara perumusan undang-undang), lembaga demokrasi dan syura yang merupakan pilar penting dalam perundang-undangan tersebut. Selain itu kajian ini juga membahas konsep negara hukum dalam siyasah dan hubungan timbal balik antara pemerintah dan warga negara serta hakhak warga negara yang wajib dilindungi. ${ }^{35}$

Fikih siyasah dusturiyah adalah bagian fikih siyasah yang mengatur hubungan antara warga negara dengan lembaga negara yang satu dengan warga

\footnotetext{
32 Muhammad lqbal, op.cit., hlm. 15-16.

${ }^{33}$ Sri Kantun, 2016. "Uji Materiil Undang-Undang Peradilan Agama dalam Prespektif Fikih Siyasah," Al-Qanun: Jurnal Pemikiran dan Pembaharuan Hukum Islam 19 (1), hlm. 147.

${ }^{34}$ Muhakki Muhakki "Mekanisme Suara Terbanyak Bagi Pemilu Legislatif (Studi Siyasah Dusturiyah)," al-Daulah: Jurnal Hukum dan Perundangan Islam 1 (2), hlm. 135.

${ }^{35}$ Muhammad lqbal, op.cit., hlm. 177.
}

negara dan lembaga negara yang lain dalam batas-batas administratif suatu negara. Permasalahan di dalam fikih siyasah dusturiyah adalah hubungan antara pemimpin di satu pihak dan rakyatnya di pihak lain serta kelembagaan-kelembagaan yang ada di dalam masyarakat. Maka ruang lingkup pembahasannya sangat luas. Oleh karena itu, di dalam fikih siyasah dusturiyah biasanya dibatasi hanya membahas pengaturan dan perundangundangan (legislasi) yang dituntut oleh hal inwal kenegaraan dari segi persesuaian dengan prinsip-prinsip agama yang merupakan realisasi kemaslahatan umat manusia serta memenuhi kebutuhannya.

Kaitannya dalam hal ini adalah mengkaji sebuah produk hukum negara berupa peraturan perundang-undangan, yang dikaji adalah dari segi politik hukum mengenai perlindungan $\mathrm{PMI}$ harus jelas dan tepat dalam aturannya dalam melindungi hak-haknya. Politik hukum tersebut dilihat dari segi arah kebijakan dan prinsip-prinsip dasar maupun sampai aturan pelaksanaannya. Secara materi muatan UU PPMI dikaji lebih lanjut berdasarkan perspektif fikih siyasah dusturiyah dan juga dicari landasanlandasannya melalui sumber-sumber hukum Islam tersebut.

\section{Sumber-Sumber Fiqh Siyasah Dusturiyah}

Setiap disiplin ilmu mempunyai sumber-sumber dalam pengkajiannya. 
Dari sumber-sumber tersebut maka ilmu dapat berkembang sesuai tuntutan dan tantangan zaman. Demikian juga dengan fiqh siyasah dusturiyah. Sebagai salah satu cabang disiplin ilmu fikih, fiqh siyasah dusturiyah mempunyai sumbersumber yang dapat dirujuk dan dijadikan pegangan. Secara garis besar sumber figh siyasah dusturiyah dapat dibagi menjadi sumber primer dan sekunder.

Fathiyah al-Nabrawi membagi sumber-sumber figh siyasah dusturiyah kepada 3 (tiga) bagian, yaitu Al-Qur'an dan Sunnah, sumber-sumber tertulis selain Al-Qur'an dan Sunnah dan sumbersumber berupa peninggalan kaum Muslimin terdahulu. Al-Qur'an adalah sumber pokok aturan agama Islam yang utama dijadikan dasar dalam menentukan hukum. Al-Qur'an diyakini berasal dari Allah dan teks-teksnya dianggap suci, maka setiap muslim harus mengakuinya sebagai pondasi segala macam superstruktur islam. ${ }^{36}$ Sunnah secara harfiah adalah suatu praktek kehidupan yang membudaya atau suatu norma perilaku yang diterima secara komunal oleh masyarakat yang meyakininya meliputi segenap ucapan dan tingkah laku nabi Muhammad SAW. ${ }^{37}$ Sedangkan sunnah menurut istilah ulama fikih adalah sifat hukum bagi perbuatan yang dituntut memperbuatnya dalam bentuk tuntutan

\footnotetext{
${ }^{36}$ Khalid Jindan dan Masrohin. 1995, Teori Politik Islam: Telaah Kritis Ibnu Taimiyah tentang Pemerintahan Islam, Surabaya: Risalah Gusti, hlm. 51.

37 lbid., hlm. 53.
}

yang tidak pasti dengan pengertian diberi pahala orang yang melakukannya dan tidak berdosa orang yang meninggalkannya. ${ }^{38}$

Selain sumber Al-Qur'an dan Sunnah, Ahmad Sukardja memberikan sumber fiqh siyasah dusturiyah yaitu berasal dari manusia itu sendiri dan lingkungannya, seperti pandangan para pakar politik, 'urf atau kebiasaan masyarakat yang bersangkutan, adat istiadat setempat, pengalaman masa lalu dan aturan-aturan yang pernah dibuat sebelumnya. ${ }^{39}$ Sumber-sumber tersebut dapat berasal dari ijma (konsensus), yaitu merupakan suatu keputusan bersama untuk menentukan suatu hukum yang baik demi kemaslahatan umat dengan cara musyawarah. Kemudian dengan menggunakan qiyas. Qiyas adalah metode logika yang digunakan untuk memecahkan suatu masalah yang berkenaan dengan legalitas suatu bentuk perilaku tertentu dengan cara menetapkan satu kaitan positif atau negatif antara bentuk perilaku yang satu dengan bentuk perilaku yang lainnya dengan suatu prinsip umum. ${ }^{40}$

\footnotetext{
${ }^{38}$ Abdul Majid Asy-Syarafi, ljtihad Kolektif, 1 ed. 2002, Jakarta: Pustaka Al-Kautsar, hlm. 9.

39 Ahmad Sukardja dan Ahmad Sukardja. 2012. Piagam Madinah \& Undang-Undang Dasar 1945 NRI 1945: Kajian Perbandingan tentang Dasar Hidup Bersama dalam Masyarakat yang Majemuk, Cet. 1, Rawamangun, Jakarta: Sinar Grafika, hlm. 11.

40 lbid, hlm. 56.
} 


\section{Fiqh Siyasah Dusturiyah Mengenai Perlindungan Pekerja Migran}

Menurut Sony Sumarsono dalam bekerja erat kaitannya dengan tenaga kerja, yaitu meliputi mereka yang bekerja untuk diri sendiri maupun anggota keluarga yang tidak menerima bayaran berupa upah atau mereka yang sesungguhnya bersedia dan mampu untuk bekerja, dalam arti mereka menganggur dengan terpaksa karena tidak ada kesempatan kerja. ${ }^{41}$ Jadi tenaga kerja adalah semua orang yang bersedia dan sanggup bekerja. ${ }^{42}$ Pasal 1 angka 2 UU Ketenagakerjaan memberikan pengertian yang dimaksud dari tenaga kerja adalah "Setiap orang yang mampu melakukan pekerjaan guna menghasilkan barang dan/atau jasa baik untuk memenuhi kebutuhan sendiri maupun untuk masyarakat". Berdasarkan firman Allah SWT;

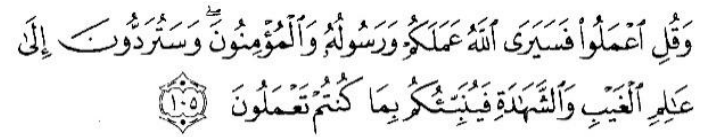

Artinya: "Dan katakanlah: Bekerjalah kamu, maka Allah dan RasulNya serta orang-orang mukmin akan melihat pekerjaan mu itu dan kamu akan dikembalikan kepada Allah Yang Maha Mengetahui akan ghaib dan yang nyata,

\footnotetext{
41 Sonny Sumarsono. 2003, Ekonomi Manajemen Sumberdaya Manusia dan Ketenagakerjaan, Ed. 1., cet. 1, Yogyakarta: Graha IImu, hlm. 2.

42 M.B. Hendri Anto, Op. Cit., hlm. 17.
}

lalu diberikan-Nya kepada kamu apa yang kamu kerjakan. (At-Taubah: 105)

Quraish Shihab dalam menafsirkan surat At-Taubah ayat 105 menjelaskan dalam kitabnya Tafsir AlMisbah sebagai berikut: "Bekerjalah kamu, demi karena Allah semata dengan aneka amal yang saleh dan bermanfaat, baik untuk diri kamu maupun untuk masyarakat umum, maka Allah akan melihat yakni menilai dan memberikan ganjaran amal kamu itu". ${ }^{43}$ Maka dengan demikian, Islam mendorong umatnya untuk bekerja dan memproduksi, semua jenis kerja yang dilakukan fisik atau pikiran. Bahkan menjadikannya sebuah kewajiban terhadap orang-orang yang mampu, lebih dari itu Allah akan memberikan balasan yang setimpal yang sesuai dengan amal/kerja, sesuai dengan firman Allah;

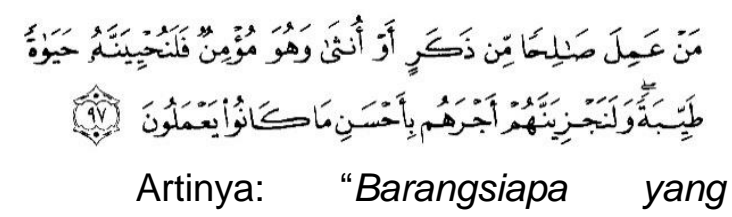
mengerjakan amal saleh, baik laki-laki maupun perempuan dalam Keadaan beriman, Maka Sesungguhnya akan Kami berikan kepadanya kehidupan yang baik dan Sesungguhnya akan Kami beri balasan kepada mereka dengan pahala yang lebih baik dari apa yang telah mereka kerjakan". (Q.S An-Nahl: 97)

\footnotetext{
43 Moh Quraish Shihab. 2005, Tafsir al-Mishbāh: Pesan, Kesan, dan Keserasian al-Qur'an, Cet. 6, Ciputat, Jakarta: Lentera Hati, hlm. 670.
} 
Berkaitan dengan hal tersebut hak untuk mendapatkan pekerjaan dijamin dalam konstitusi negara Indonesia, merupakan hak asasi bagi setiap warga negara. Arif Budiman menjelaskan bahwa hak asasi manusia adalah hak kodrati manusia, begitu manusia dilahirkan, langsung hak asasi itu melekat pada dirinya sebagai manusia. ${ }^{44}$ Sesuai dengan tujuan negara menciptakan kemaslahatan bagi seluruh masyarakatnya, maka negara mempunyai tugas-tugas penting untuk merealisasikan tujuan tersebut. ada 3 (tiga) tugas utama negara. Pertama, menciptakan peraturan perundang-undangan yang sesuai dengan ajaran Islam. Kedua, melaksanakan undang-undang tersebut. Ketiga, mempertahankan hukum dan undang-undang yang telah dibuat.

Berdasarkan Pasal 31 UndangUndang Nomor 13 Tahun 2003 tentang Ketenagakerjaan (UUTK) menentukan bahwa "Setiap tenaga kerja mempunyai hak dan kesempatan yang sama untuk memilih, mendapatkan, atau pindah pekerjaan dan memperoleh penghasilan yang layak di dalam atau di luar negeri. Maka warga negara Indonesia (WNI) diberikan hak untuk tidak hanya mencari pekerjaan di dalam negeri tetapi sampai keluar negeri. Tidak sedikit WNI bekerja di luar negeri, pemerintah pun tidak

44 Sri Warjiyati. 2018, "Instrumen Hukum Penegakan Hak Asasi Manusia," Jurnal Justicia Islamica 15 (1), hlm. 121. tinggal diam dengan membuat berbagai produk hukum agar kepastian dan perlindungan para WNI yang bekerja diluar negeri dapat terjaga.

Berdasarkan Pasal 1 angka 5 UU PPMI menentukan bahwa, Perlindungan Pekerja Migran Indonesia adalah segala upaya untuk melindungi kepentingan Calon Pekerja Migran Indonesia dan/atau Pekerja Migran Indonesia dan keluarganya dalam mewujudkan terjaminnya pemenuhan haknya dalam keseluruhan kegiatan sebelum bekerja, selama bekerja, dan setelah bekerja dalam aspek hukum, ekonomi, dan sosial. Selain itu UU PPMI juga bertujuan agar PMI harus dilindungi dari perdagangan manusia, perbudakan dan kerja paksa, korban kekerasan, kesewenangwenangan, kejahatan atas harkat dan martabat manusia, serta perlakuan lain yang melanggar hak asasi manusia berdasarkan asas-asas perlindungan PMI yang diatur dalam Pasal 2 UU PPMI. Secara filosofis mengenai perlindungan PMI, arah kebijakan UU PPMI tersebut agar hak asasi manusia (HAM) para PMI dapat terjaga dan ditegakkan, baik saat mereka masih berada di Indonesia yaitu, sebelum bekerja dan selama maupun setelah bekerja di luar negeri. Hal tersebut sesuai dengan 4 (empat) prinsip ketenagakerjaan dalam Islam yaitu;

a. Kemerdekaan manusia.

$\begin{array}{ccr}\text { Ajaran } & \text { Islam } & \text { yang } \\ \text { direpresentasikan } & \text { dengan } & \text { aktivitas } \\ \text { kesalehan sosial } & \text { Rasulullah } & \text { SAW yang }\end{array}$


dengan tegas mendeklarasikan sikap anti-perbudakan untuk membangun tata kehidupan masyarakat yang toleran dan berkeadilan. Islam tidak mentolerir sistem perbudakan dengan alasan apa pun. Terlebih lagi adanya praktik jual-beli pekerja dan pengabaian hak-haknya yang sangat tidak menghargai nilai-nilai kemanusiaan.

Hal ini sesuai dengan ketentuan dalam Pasal 2 UU PPMI mengenai asas anti-perdagangan manusia dan asas persamaan hak. Berdasarkan firman Allah SWT;

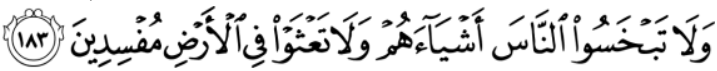

Artinya: "Dan janganlah kamu merugikan manusia pada hak-haknya dan janganlah kamu merajalela di muka bumi dengan membuat kerusakan". (Q.S AsSyua'ara: 183)

Selaras dengan hal tersebut UU PPMI telah melarang segala bentuk perdagangan manusia. Pengertian antiperdagangan manusia adalah bahwa tidak adanya tindakan perekrutan, pengangkutan, pengiriman, pemindahan, atau penerimaan calon dan/atau PMI dengan ancaman kekerasan, penggunaan kekerasan, penculikan, penyekapan, pemalsuan, penipuan dan penyalahgunaan kekuasaan atau posisi rentan. Proses sebelum, selama dan setelah bekerja PMI juga dilindungi dari segala bentuk macam modus penjeratan uang, memberikan bayaran atau manfaat sehingga memperoleh persetujuan dari orang yang memegang kendali atas orang lain tersebut, baik yang dilakukan di dalam negara maupun antar negara, untuk tujuan eksploitasi atau mengakibatkan tereksploitasi. UndangUndang PPMI juga mengakomodir persamaan hak dalam pengaturannya. Pengertian asas persamaan hak adalah bahwa calon dan/atau PMI mempunyai hak, kesempatan dan perlakuan yang sama untuk memperoleh pekerjaan dan penghidupan yang layak.

b. Prinsip kemuliaan derajat manusia.

Agama Islam menempatkan setiap manusia, apa pun jenis pekerjaan dan profesinya dalam posisi yang mulia dan terhormat. Islam juga sangat mencintai umat Muslim yang gigih bekerja untuk kehidupannya. Allah SWT menegaskan hal tersebut dalam AI-Qur'an yaitu;

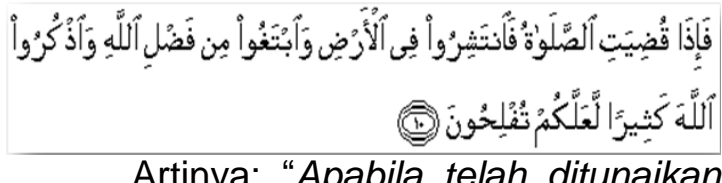
sholat, maka bertebaranlah kalian di mukabumi, dan carilah karunia Allah, dan ingatlah Allah banyak-banyak supaya kalian beruntung." (QS. Al-Jumu'ah: 10)

Ayat ini diperkuat hadis yang diriwayatkan oleh Imam Al-Baihaqi: "Tidaklah seorang di antara kamu makan suatu makanan lebih baik daripada memakan dari hasil keringatnya sendiri'. Hal ini sesuai dengan ketentuan dalam Pasal 2 UU PPMI mengenai asas pengakuan atas martabat dan hak asasi manusia dan asas nondiskriminasi. Pertama, asas pengakuan atas martabat 
dan hak asasi manusia adalah bahwa perlindungan PMI harus mencerminkan penghormatan terhadap keberadaan manusia sebagai makhluk Tuhan Yang Maha Esa demi kehormatan serta perlindungan harkat dan martabat manusia. Kedua, pengertian asas nondiskriminasi adalah bahwa perlindungan PMI dilakukan tanpa adanya pembedaan perlakuan yang langsung ataupun tidak langsung didasarkan pada pembedaan manusia atas dasar agama, suku, ras, etnis, kelompok, golongan, status sosial, status ekonomi, jenis kelamin, bahasa, dan keyakinan politik.

c. Prinsip keadilan.

Keadilan penting bagi kehidupan manusia demi terciptanya penghormatan dan hak-hak yang layak sesuai dengan aktifitasnya. Berdasarkan firman Allah SWT;

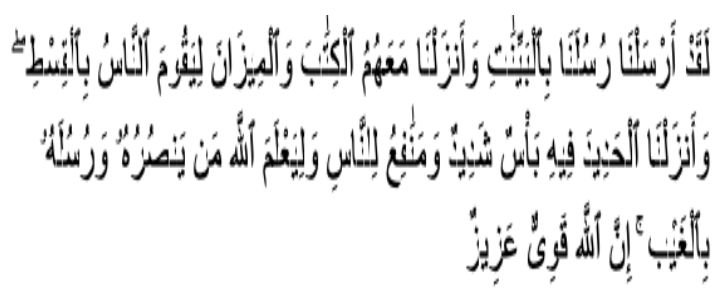

Artinya: "Sesungguhnya Kami telah mengutus rasul-rasul Kami dengan membawa bukti-bukti yang nyata dan telah Kami turunkan bersama Al-Kitab dan neraca (keadilan) supaya manusia dapat melaksanakan keadilan. Dan kami ciptakan besi yang padanya terdapat kekuatan yang hebat dan berbagai manfaat bagi manusia, (supaya mereka mempergunakan besi itu) dan supaya Allah mengetahui siapa yang menolong
(agama)Nya dan rasul-rasul-Nya padahal Allah tidak dilihatnya. Sesungguhnya Allah Maha Kuat lagi Maha Perkasa". (QS. Al-Hadid: 25)

Adil dalam pengertian ini adalah yang dimaksudkan juga dalam penyelenggaraan sarana-sarana penghidupan. Keadilan yang harus ditegakkan adalah terlaksananya kehidupan atas dasar keseimbangan, yang kuat menolong yang lemah, yang kaya membantu yang miskin, sebaliknya yang lemahpun mendukung tegaknya keadilan dengan jalan yang baik, bukan dengan merongrong kepada yang kuat, yang miskin pun jangan merongrong yang kaya.

Selanjutnya di samping itu keadilan dalam bidang ketenagakerjaan juga pada cara-cara memperoleh produksi, pendistribusian serta dalam pemanfaatannya. Berkaitan dengan hal ini maka berhubungan dengan asas transparansi yang diatur dalam Pasal 2 UU PPMI, yang dimaksud dengan asas transparansi adalah bahwa, perlindungan PMI dilakukan secara terbuka, jelas, dan jujur.

d. Prinsip kejelasan akad (perjanjian) dan transaksi upah

$\begin{array}{clr}\text { Agama } & \text { Islam } & \text { sangat } \\ \text { memperhatikan } & \text { masalah akad }\end{array}$
(perjanjian). Akad termasuk salah satu bagian terpenting dalam kehidupan perekonomian. Setiap orang beriman wajib untuk menunaikan apa yang telah diperjanjikan, baik yang berkaitan dengan 
pekerjaan, upah, waktu bekerja dan sebagainya. Akad merupakan keharusan untuk dibuat dalam rangka mengatur secara praktis hubungan pekerja dan majikan yang meliputi: etika, hak dan kewajiban antara kedua belah pihak.

Berdasarkan firman Allah SWT;

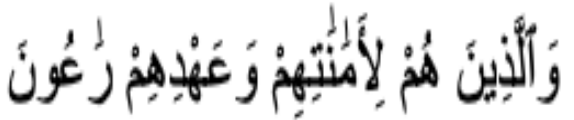

Artinya: "Dan mereka yang memelihara amanah dan menempati janji" (Q.S Al Mukminuun: 8)

Selanjutnya perjanjian juga menegaskan nilai keadministrasian dan memegang teguh nilai moral yang berkaitan dengan kehalalan, legalitas dan etis. Mengingat hal itu maka dalam transaksi amat diperlukan keterbukaan sehingga sikap spekulatif, penipuan, kolusi, korupsi dan lain-lain dalam berbagai kegiatan ekonomi dapat dihindari dan hal itu diharamkan oleh Islam karena praktek penipuan pasti akan merugikan pihak tertentu. Upah atau gaji adalah hak pemenuhan ekonomi bagi pekerja yang menjadi kewajiban dan tidak boleh diabaikan oleh para majikan atau pihak yang mempekerjakan. Berdasarkan firman Allah SWT;

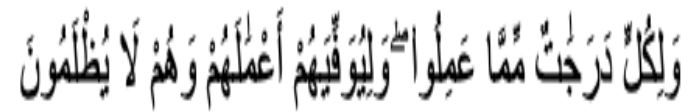

Artinya: "Dan bagi masing-masing mereka derajat menurut apa yang telahmereka kerjakan dan agar Allah mencukupkan bagi mereka (balasan) pekerjaan-pekerjaan mereka sedang mereka tiada dirugikan". (Q.S Al-Ahqaf: 19)

Sangat pentingnya masalah upah pekerja ini, Islam memberi pedoman kepada para pihak yang mempekerjakan orang lain bahwa prinsip pemberian upah harus mencakup dua hal, yaitu; 1) adil dan 2) mencukupi. Prinsip tersebut terangkum dalam sebuah hadis Nabi yang diriwayatkan Imam Al-Baihaqi, "Berikanlah gaji kepada pekerja sebelum kering keringatnya, dan beritahukan ketentuan gajinya, terhadap apa yang dikerjakan..$^{45}$ Selain itu sebagaimana juga diriwayatkan oleh Imam Bukhori, Muslim dan Ahmad, "Rasulullah SAW berbekam, lalu beliau membayar upahnya kepada orang yang berbekamnya". 46

Prinsip kejelasan akad dan upah dalam agama Islam sesuai dengan ketentuan pengaturan perlindungan terhadap PMI sebelum bekerja yaitu pada Pasal 8 yang mencakup 2 aspek yaitu administratif dan teknis. Perlindungan yang bersifat administratif meliputi kelengkapan dan keabsahan dokumen penempatan serta penetapan kondisi dan syarat kerja. Perlindungan pada aspek teknis meliputi antara lain sosialisasi informasi, pendidikan dan pelatihan, fasilitas pemenuhan hak, pelayanan dalam bentuk layanan terpadu satu atap

\footnotetext{
${ }^{45}$ Afzal-ur-Rahman. 1994. Doktrin Ekonomi Islam, Kuala Lumpur: Dewan Bahasa dan Pustaka, hlm. 248-252.

${ }^{46}$ M. Ali Hasan. 2003, Berbagai Macam Transaksi dalam Islam (Figh Muamalat), Jakarta: RajaGrafindo Persada, hlm. 161.
} 
(LTSA). Kemudian, berdasarkan Pasal 19 UU PPMI, bagian perlindungan sebelum bekerja mengatur tentang isi perjanjian kerja, jangka waktu perjanjian kerja, prosedur perpanjangan perjanjian kerja, serta sanksi administratif bagi PPPMI yang tidak menempatkan calon PMI sesuai yang tercantum dalam perjanjian kerja. Termasuk kejelasan pemberian upah di dalam perjanjian kerja tersebut.

Secara garis besar prinsip-prinsip ketenagakerjaan dalam Islam diatas dapat tercermin dari pemberian hak kepada calon dan/atau PMI. Pengaturan mengeni hak-hak yang diberikan kepada calon dan/atau PMI terdapat pada Pasal 6 ayat 1 menentukan bahwa Setiap Calon Pekerja Migran Indonesia atau Pekerja Migran Indonesia memiliki hak: a) mendapatkan pekerjaan di luar negeri dan memilih pekerjaan sesuai dengan kompetensinya; b) memperoleh akses peningkatan kapasitas diri melalui pendidikan dan pelatihan kerja; c) memperoleh informasi yang benar mengenai pasar kerja, tata cara penempatan, dan kondisi kerja di luar negeri; d) memperoleh pelayanan yang profesional dan manusiawi serta perlakuan tanpa diskriminasi pada saat sebelum bekerja, selama bekerja, dan setelah bekerja; e) menjalankan ibadah sesuai dengan agama dan keyakinan yang dianut; f) memperoleh upah sesuai dengan standar upah yang berlaku di negara tujuan penempatan dan/atau kesepakatan kedua negara dan/atau
Perjanjian Kerja; g) memperoleh pelindungan dan bantuan hukum atas tindakan yang dapat merendahkan harkat dan martabat sesuai dengan ketentuan peraturan perundang-undangan di Indonesia dan di negara tujuan penempatan; h) memperoleh penjelasan mengenai hak dan kewajiban sebagaimana tertuang dalam Perjanjian Kerja; i) memperoleh akses berkomunikasi; j) menguasai dokumen perjalanan selama bekerja; k) berserikat dan berkumpul di negara tujuan penempatan sesuai dengan ketentuan peraturan perundang-undangan yang berlaku di negara tujuan penempatan; I) memperoleh jaminan pelindungan keselamatan dan keamanan kepulangan Pekerja Migran Indonesia ke daerah asal; dan/atau $\mathrm{m}$ ) memperoleh dokumen dan Perjanjian Kerja Calon Pekerja Migran Indonesia dan/atau Pekerja Migran Indonesia.

\section{Penutup}

Pemerintah dalam melindungi pekerja migran telah mengeluarkan kebijakan berupa Undang-Undang Nomor 18 Tahun 2017 tentang Perlindungan Pekerja Migran Indonesia (UU PPMI). Perlindungan pekerja migran Indonesia berdasarkan politik hukumnya berlandaskan pada Pasal 28A UUD 1945 yang menentukan bahwa, setiap orang berhak untuk hidup serta berhak mempertahankan hidup dan kehidupannya. Maka berdasarkan hal tersebut perkembangan hukum 
perlindungan PMI dimulai dari lahirnya UU PPTKILN 2004 kemudian pada tahun 2012 pemerintah meratifikasi Konvensi Buruh Migran 1990 sampai pada lahirnya Undang-Undang Nomor 18 Tahun 2017 tentang Perlindungan Pekerja Migran Indonesia. Upaya pemerintah tersebut bertujuan untuk melindungi hak PMI sebagai warga negara yang dilindungi oleh negara dan konstitusi. Berdasarkan Pasal 3 UU PPMI memberikan arah tujuan yang hendak dicapai dalam perlindungan PMI yaitu; a) menjamin pemenuhan dan penegakan HAM PMI; dan b) menjamin perlindungan hukum, ekonomi, dan sosial PMI dan keluarganya. Perlindungan PMI tersebut dilaksanakan yaitu sebelum, selama dan setelah bekerja. Materi muatan mengenai perlindungan PMI dalam UU PPMI tersebut ditinjau dari perspektif fikih siyasah dusturiyah sesuai dengan 4 (empat) prinsip ketenagakerjaan dalam Islam yaitu; 1) kemerdekaan manusia; 2) prinsip kemuliaan derajat manusia; 3) prinsip keadilan; dan 4) prinsip kejelasan akad (perjanjian) dan transaksi upah.

\section{Bibliografi}

\section{Buku:}

Afzal-ur-Rahman. 1994. Doktrin Ekonomi Islam. Kuala Lumpur: Dewan Bahasa dan Pustaka.

Anto, M.B. Hendri. 2003. Pengantar Ekonomi Mikro Islam. Yogyakarta: Ekonisia UII.
Asy-Syarafi, Abdul Majid. 2002. Ijtihad Kolektif. 1 ed. Jakarta: Pustaka AlKautsar.

Badan Pusat Statistik Indonesia. 2019. Berita Resmi Statistik Keadaan Ketenagakerjaan Indonesia 2019.

2020.

Berita Resmi Statistik Keadaan

Ketenagakerjaan Februari 2020.

Hasan, M. Ali. 2003. Berbagai Macam

Transaksi dalam Islam (Fiqh

Muamalat). Jakarta: RajaGrafindo

Persada.

Iqbal, Muhammad. 2001. Fiqh Siyasah:

Kontekstualisasi Doktrin Politik Islam.

Jakarta: Gaya Media Pratama.

Jindan, Khalid, dan Masrohin. 1995. Teori

Politik Islam: Telaah Kritis Ibnu Taimiyah tentang Pemerintahan Islam. Surabaya: Risalah Gusti.

Kairys, David, ed. 1990. The Politics of Law: a Progressive Critique. Revised ed. (2nd ed.). New York: Pantheon Books.

Pusat Analisis Dan Evaluasi Hukum Nasional Badan Pembinaan Hukum Nasional Kementerian Hukum Dan Hak Asasi Manusia. 2016. Laporan Akhir Analisis Dan Evaluasi Hukum Mengenai Perlindungan Hak Dan Keselamatan Pekerja Migran.

Manzhur, Ibn. 1968. Lisan al-Arab. Juz 6.

Beirut: Dar al-Shadr.

Mertokusumo, Sudikno. Mengenal Hukum Suatu Pengantar. Yogyakarta: Liberty, 2008. 
Moh. Mahfud M. D. 2009. Politik Hukum di Indonesia. Jakarta: Rajawali Pers.

Parsons, Talcott. 1966. Societiers, Evolutionary and Comparative Perspectives. Englewood Cliff, New Jersey: Prentice Hall.

Pulungan, J. Suyuthi. 1999. Fiqh Siyasah: Ajaran, Sejarah dan Pemikiran. Jakarta: PT RajaGrafindo Persada.

Rahardjo, Satjipto. 2009. Hukum dan Perubahan Sosial. Yogyakarta: Genta Publishing. IImu Hukum. 2014. Bandung:

Citra Aditya Bakti.

Rosadi, Otong, dan Andill Desmon. 2013. Studi Politik Hukum: Suatu Optik Politik Hukum. II. Yogyakarta: PT. Thafa Media.

Shihab, Moh Quraish. 2005. Tafsir alMishbāh: Pesan, Kesan, dan Keserasian al-Qur'an. Cet. 6. Ciputat, Jakarta: Lentera Hati.

Soerjono Soekanto. 2006. Penelitian Hukum Normatif. Rajawali Pub.

Sukardja, Ahmad, dan Ahmad Sukardja. 2012. Piagam Madinah \& UndangUndang Dasar 1945 NRI 1945: Kajian Perbandingan tentang Dasar Hidup Bersama dalam Masyarakat yang Majemuk. Cet. 1. Rawamangun, Jakarta: Sinar Grafika.

Sumarsono, Sonny. 2003. Ekonomi Manajemen Sumberdaya Manusia dan Ketenagakerjaan. Ed. 1., cet. 1. Yogyakarta: Graha IImu.
Taimiyah, Ibn. Siyasah al-Syar'iyah fi Ishlah al-Ra'l wa al-Ra'iyah. Mesir: Dar al-Kitab al-Arabi, t.t.

Wisnuwardhani, Savitri. 2018. Memahami Undang-Undang Perlindungan Pekerja Migran Indonesia: Kelebihan dan Kelemahan UU PPMI. Jakarta: Jaringan Buruh Migran: The Institute for Ecosoc Rights.

\section{Jurnal:}

Atmaja, Hamdan Tri. 2014. "Model Pemberdayaan Keluarga Tenaga Kerja Wanita (TKW) Indonesia Berbasis Arena Produksi Kultural Dalam Upaya Menciptakan Keluarga Mandiri Sejahtera di Propinsi Jawa Timur." Forum IImu Sosial, Fakultas IImu Sosial Universitas Negeri Semarang 41 (1).

Azra, Azyumardi. 2018. "Kesalehan dan Politik: Islam Indonesia." Studia Islamika, 639-50.

Bareta, Rizky Dian, dan Budi Ispriyarso. 2018. "Politik Hukum Perlindungan Tenaga Kerja Indonesia Fase Purna Bekerja." Kanun Jurnal IImu Hukum 20 (1): 163-82.

De La Vega, Connie, dan Conchita Lozano-Batista. 2016. "21 Advocates Should Use Applicable International Standards to Address Violations of Undocumented Migrant Workers' Rights in the United States." Dalam Human Rights and Refugees, Internally Displaced Persons and 
Migrant Workers, disunting oleh Anne

F. Bayefsky, 517-50. Martinus Nijhoff Publishers.

Kantun, Sri. 2016. “Uji Materiil Undangundang Peradilan Agama dalam Prespektif Fikih Siyasah." Al-Qanun: Jurnal Pemikiran dan Pembaharuan Hukum Islam 19 (1): 147-69.

Muhakki, Muhakki. 2011. "Mekanisme Suara Terbanyak Bagi Pemilu Legislatif (Studi Siyasah Dusturiyah)." al-Daulah: Jurnal Hukum dan Perundangan Islam 1 (2): 135-58.

Natalis, Aga, dan Budi Ispriyarso. 2018. "Politik Hukum Perlindungan Pekerja Migran Perempuan di Indonesia." Pandecta: Research Law Journal 13 (2): 109-23.

Prihatinah, Tri Lisiani, Noor Asyik, dan Kartono Kartono. 2012. "Kendala Perlindungan Hukum Terhadap Buruh Migran di Kabupaten Cilacap." Jurnal Dinamika Hukum 12 (2).

Warjiyati, Sri. 2018. "Instrumen Hukum Penegakan Hak Asasi Manusia." Jurnal Justicia Islamica 15 (1).
Widaningrum, Ambar. 2017. "Public Trust and Regulatory Compliance." Jurnal IImu Sosial dan IImu Politik 21 (1): 1.

Internet:

Depnakertrans Bantah RUU Perlindungan TKI Mengukuhkan Trafficking. http://www.tempointeraktif.com/hg/na sional/2004/09/17/brk,2004091731 ,id.html. diakses pada tanggal 25 Desember 2019

Komnas HAM, "Hak Asasi Buruh Migran Indonesia. http://www. tempointeraktif.com/hg/narasi/2004/0 6/17/nrs,20040617-07,id.html. diakses pada tanggal 25 Desember 2019

Pemerintah Hanya Jadikan TKI Sebagai Komoditas.

http://www.eramoslem.com/br/fo/48/1 $2377,1 \mathrm{v} . \mathrm{html}$. diakses pada tanggal 25 Desember 2019 